\title{
Maitotilayrittäjien informaatiolähteet muuttuvan liiketoimintaympäristön analysoinnissa
}

\author{
Susanna Lahnamäki-Kivelä \\ Jyväskylän ammattikorkeakoulu, Biotalousinstituutti, Tuumalantie 17, 43130, etunimi.sukunimi@jamk.fi
}

\section{TIIVISTELMÄ}

Maitotilayrittäjät kohtaavat jatkuvasti muutoksia toimintaympäristössään. Samaan aikaan rakennekehitys haastaa tilakokoja kasvamaan ja maitotilayrittäjiä kasvattamaan maidontuotantoa. Kasvuhaasteeseen vastaaminen edellyttää yrittäjältä vahvaa johtamisosaamista ja toimintaympäristön muutosten tunnistaminen edellyttää perusteellista liiketoimintaympäristön analysointia strategisten päätösten tekemiseksi. Strategisten päätösten ollessa pitkäkestoisia, on yrittäjän hankittava tietoa tulevaisuuden toimintaympäristön mahdollisista kehityssuunnista. Varautuminen erilaisiin muutoksiin parantaa maitotilayrittäjän mahdollisuuksia ylläpitää maataloustuotannon kannattavuutta ja elinvoimaa.

Tässä tutkimuksessa selvitetään millaisia tietokanavia maitotilayrittäjät käyttävät strategisessa päätöksenteossa. Aineisto koottiin sähköisellä kyselyllä helmi-maaliskuussa 2019 ja siihen vastasi 135 maitotilayrittäjää eri puolilta Suomea. Kyselyyn vastanneiden tilojen keskikoko oli 69 lypsävää, 106 ha peltoa hallinnassa, ja tiloilla oli keskimäärin $9950 \mathrm{~kg}$ keskituotos. Vastanneiden yrittäjien ikä oli 44 vuotta ja vastaajista $57 \%$ oli naisia. Kyselyyn vastanneet yrittäjät edustivat hieman keskivertoa suurempia tiloja ja nuorempia yrittäjiä. Yrittäjistä huomattavalla osalla oli opisto-, amk- tai yliopistotutkinto maatalouden alalta. Vastanneista yrittäjistä 58.5\% ilmoitti tilallaan olevan aikeita kasvattaa maidontuotantoa.

Maitotilayrittäjät arvioivat erilaisia tietolähteitä ja niiden merkitystä omissa pitkävaikutteisissa investointipäätöksissä 5-portaisella Likert-asteikolla. Kyselyssä esillä olleet tietolähteet olivat sekä maidontuotantoon suoraan liittyviä lähteitä, että laajempia yhteiskunnallisia ja markkinatalouden muutoksia käsitteleviä tietolähteitä. Tietolähteissä oli paitsi suoraan maitotilan johtamiseen liittyviä lähteitä, myös erilaisia tulevaisuuden kehitysnäkymiä kuvaavia lähteitä. Analysoinnissa käytettiin faktorianalyysiä, jonka tuloksena tunnistettiin neljä erilaista tietolähderyhmää, joita yrittäjät hyödyntävät arvioidessaan liiketoimintaympäristön kehittymistä. Ryhmät kuvaavat verkostoja, liiketoimintaympäristöä ja asiantuntijoita tietolähteinä sekä laajempaa toimintaympäristön muutosten arviointia.

Jatkoanalyyseissä selvitetään vaikuttavatko yrittäjien tulevaisuuden suunnitelmat käytettäviin tietolähteisiin. Tätä tietoa voidaan hyödyntää maitotilayrittäjille tarjottavien johtamisen ja liiketoimintakoulutusten sisältöjen suunnittelussa.

Asiasanat: maidontuotanto, liiketoimintaympäristö, ennakointi

\section{Johdanto}

Rakennekehitys on johtanut suomalaisten maitotilojen määrän vähenemiseen ja samanaikaisesti jatkavien tilojen koon kasvuun. Kasvuinvestointien polulle lähteneet maatilayrittäjät kohtaavat vahvan johtamisosaamisen vaatimuksen sekä päivittäisessä että strategisessa yritysjohtamisessa (Perkiö-Mäkelä ym. 2016). Yrityksen johtajan tärkeimpiin tehtäviin kuuluu yrityksen jatkon turvaaminen Carinin ja Normanin (2017) mukaan. Kun kyseessä on pitkään jatkuva yritystoiminta, kuten maitotilayrittäjyys, on yrittäjän sopeuduttava epävarmuuteen liiketoimintaympäristössään (Groenewald 1987). Epävarmuudet toimintaympäristössä syntyvät useissa eri lähteissä ja ne vaikuttavat yrityksen johtamiseen (Haase ja Franco 2011) sekä haastavat yrittäjän toimintaa (Hough ja White 2004). Strategisten päätösten ollessa pitkäkestoisia, on yrittäjän etu hankkia tietoa tulevaisuuden toimintaympäristön mahdollisista 
kehityssuunnista. Näin mahdollistetaan varautuminen erilaisiin muutoksiin sekä parantaa maitotilayrittäjän mahdollisuuksia ylläpitää maataloustuotannon kannattavuutta ja elinvoimaa.

Erityisesti nuoret suomalaiset maatalousyrittäjät ovat suuntautuneet tilan liiketoiminnan kehittämiseen investoimalla yritykseen (Perkiö-Mäkelä ym. 2016). Maidontuotannossa tuotantoa laajentavat investoinnit ovat pitkävaikutteisia ja sitovat vierasta pääomaa yritykseen pitkäksi aikaa. Tämän vuoksi on yrityksen jatkuvuudelle tärkeää kyetä analysoimaan liiketoimintaympäristöä ja ennakoimaan siinä käynnissä olevia muutoksia. Haase ja Franco (2011) toteavat nykyisiin ja tuleviin muutoksiin reagoimisen sekä niihin valmistautumisen edesauttavat yrityksen selviytymistä tulevaisuuden toimintaympäristössä. Toimintaympäristön tavoitteellinen analysointi voi lisätä yrittäjän kykyä havaita muutoksia ja parantaa yrittäjän mahdollisuuksia muokata omaa yritystoimintaansa muuttavassa toimintaympäristössä pärjääväksi. Ennakointi on kuitenkin vaativa tehtävä (Appiah ja Sarpong 2015) ja haastavaa rajallisilla resursseilla. Maitotilayrittäjillä muun muassa käytettävissä oleva aikaresurssi voi aiheuttaa haasteita ennakoinnin toteuttamiseksi.

Ennakointi edellyttää erilaisten tietolähteiden seuraamista ja kertyvän tiedon tulkintaa yritystoiminnassa tehtävien päätösten tueksi. Pk-yritysten osalta laajan ennakointityön haasteena ovat käytettävissä olevat rajalliset resurssit (Haase ja Franco 2011). Haase ja Franco (2011) toteavat aiempia tutkimuksia yhteen vetäessään, pääosan pk-yritysten käyttämien ennakointitietolähteiden löytyvän yritysten sisäistä lähteistä.

Tutkimuksen tavoitteena on selvittää millaiset tietolähteet ovat maitotilayrittäjille merkittäviä päätöksenteon tukena ja onko eri tietolähteillä yhdistäviä tekijöitä. Tutkimuskysymys on noussut esiin käytännön kehittämistyössä useiden maatalousyrittäjien kanssa käytyjen keskustelujen myötä. Tutkimuksessa keskitytään selvittämään aiemman kirjallisuuden pohjalta tunnistettuja kanavia hakea tietoa pitkän tähtäimen päätöksenteon tueksi.

\section{Tutkimusaineisto ja menetelmät}

Tutkimusaineisto koottiin sähköisellä kysellä vuoden 2019 aikana. Webropol-kyselyyn vastasi helmimaaliskuun aikana 135 maitotilayrittäjää $\mathrm{AB}$ - ja $\mathrm{C}$-alueilta. Kyselyn linkki oli avoinna kolme viikkoa Valion Valma -sivulla. Samalla kyselyllä koottiin tutkimusaineistoa isompaan tutkimuskokonaisuuteen. Ennen kyselyn julkaisemista se testattiin koeryhmällä, jonka antamien arvioiden mukaan kyselyä ei pidetty liian pitkänä. Kuitenkin yli 60 kyselyn aloittanutta oli jättänyt vastaamisen kesken ja tästä voidaan päätellä kyselyn olleen kokonaisuudessaan liian raskas vastattavaksi.

Kyselyssä yrittäjät vastasivat itseään ja maitotilaa koskeviin taustamuuttujakysymyksiin. Tämän lisäksi yrittäjät vastasivat kysymyksiin tilan tulevasta kehityssuunnasta valitsemalla neljästä vaihtoehdosta sopivat (kyllä/ei -vaihtoehdot): luopuu maidontuotannosta, maidontuotanto pienenee, maidontuotanto pysyy nykytasolla tai maidontuotanto kasvaa. Tulevaisuusaikomuksiensa lisäksi yrittäjät arvioivat 17 tulevaisuustietolähdettä koskevan väittämän sopivuutta omaan toimintaansa ja tilansa kehittämiseen 5 portaisella Likert -asteikolla (täysin eri mieltä, jokseenkin eri mieltä, ei osaa sanoa, jokseenkin samaa mieltä, täysin samaa mieltä). Kyselyssä esillä olleet tietolähteet olivat sekä maidontuotantoon suoraan liittyviä lähteitä, että laajempia globaaleja, yhteiskunnallisia ja markkinatalouden muutoksia käsitteleviä tietolähteitä. Kysymysten muotoilussa hyödynnettiin aiempien maatalousyrittäjien päätöksentekoa selvittäneiden tutkimuksien sekä pk-yrityksien ennakointityöhön keskittyneiden tutkimuksien tuloksia kuten Savioz ja Blum (2002), Hansson ja Ferguson (2011), Rikkonen ym. (2013) sekä Bourgeois ja Sette (2017). 
Aineiston analysointi eteni kuvailevista analyyseista eksploratiiviseen faktorianalyysiin, jonka avulla voidaan tunnistaa latentteja muuttujia laajemmasta muuttujajoukosta (Hair ym. 2010, Field 2018). Faktorianalyysin luotettavuudelle merkityksellistä on aineiston sopivuus faktoroitavaksi, tätä arvioidaan Kaiser-Meyer-Olkinin testillä. KMOn arvon tulisi olla vähintään 0.6, jotta aineiston faktoroitavuuteen voidaan luottaa (Hair ym. 2010, Field 2018). Analyysin tuloksena syntyneiden faktoreiden luotettavuutta arvioidaan faktoreiden sisäistä validiteettia mittaavalla Cronbachin alfalla. (Hair ym. 2010, Field 2018). Faktorianalyysin luotettavuuteen vaikuttaa otoskoko ja faktorilatauksen suuruus. Isolla aineistolla faktorilatauksen hyväksyttävä taso on matalampi kuin pienemmällä aineistolla. Kun faktorilataus on 0.50, tulee havaintoja olla vähintään 120 merkitsevyyden saavuttamiseen tasolla 0.05 (Hair ym. 2010).

\section{Tulokset}

Vastaajajoukon ollessa pieni, tutkimusaineisto on luonteeltaan näyte. Kyselyn vastaajajoukko ei myöskään ole edustava otos suomalaista maidontuottajista, sillä ryhmässä korostuvat nuoremman polven yrittäjät, joilla oli jo vastaushetkellä keskiarvoa isompi maitotila. Kyselyyn vastanneiden tilojen keskikoko oli 69 lypsävää vaihteluvälin ollessa 15 - 200 lypsävää. Vastaajien tiloilla oli keskimäärin 106 ha peltoa hallinnassaan (oma ja vuokrattu peltoala), ja vastaajajoukon tiloilla oli keskimäärin $9950 \mathrm{~kg}$ keskituotos. Vastanneiden yrittäjien ikä oli 44 vuotta ja vastaajista 57\% oli naisia. Työkokemusta maitotilayrittäjänä vastaajilla oli keskimäärin 14.4 vuotta, vaihdellen juuri sukupolvenvaihdoksen tehneistä eläkkeelle siirtyviin. Yrittäjistä huomattavalla osalla oli opisto-, amk- tai yliopistotutkinto maatalouden alalta (45.9\%). Maitotilayrittäjistä 58.5\% (n=79) ilmoitti tilallaan olevan aikeita kasvattaa maidontuotantoa seuraavan kymmenen vuoden aikana. Vastaajista 8\% ilmoitti olevansa lopettamassa maidontuotannon tilallaan.

Taulukko 1. Vastaajajoukkoa kuvaavat muuttujat, määrät ja suhteelliset osuudet

\begin{tabular}{|c|c|c|}
\hline Vastaajien määrä, n=135 & $\%$ vastaajista & $\begin{array}{c}\% \text { kaikista suomalaista } \\
\text { maitotilallisista }\end{array}$ \\
\hline \multicolumn{3}{|l|}{ Viljelijän sukupuoli } \\
\hline Mies & 42.3 & $85.3 \% *$ \\
\hline Nainen & 57.0 & $14.7 \% *$ \\
\hline Ei halunnut kertoa & $0.7(1)$ & \\
\hline Vuosittainen liikevaihto & \% (n =yrittäjien määrä) & 6690 maitotilaa** \\
\hline alle $50000 €$ & $0.7(1)$ & 7\% (470 tilaa) \\
\hline $50000-100000 €$ & $7.4(10)$ & $27.6 \%$ (1 850 tilaa $)$ \\
\hline $100000-250000 €$ & $25.2(34)$ & $46.2 \%$ (3 080 tilaa) \\
\hline $250000-500000 €$ & $45.9(62)$ & $15.4 \%$ (1 030 tilaa $)$ \\
\hline $500000-750000 €$ & $12.6(17)$ & $3.1 \%$ (210 tilaa) \\
\hline $750000-1000000 €$ & $6.7(9)$ & $0.7 \%(50$ tilaa $)$ \\
\hline $1000000 €$ tai enemmän & $1.5(2)$ & \\
\hline \multicolumn{3}{|c|}{$\begin{array}{l}\text { *Suomalaisten maitotilayrittäjien sukupuoli vuonna } 2016 \text { (LUKE) } \\
\text { **Suomalaisten FADN maitotilojen määrä vuonna } 2017 \text { (Taloustohtori, LUKE) }\end{array}$} \\
\hline \multicolumn{3}{|c|}{$\begin{array}{l}\text { Maitotilayrittäjien suhtautuminen erilaisiin tietolähteisiin vaihteli runsaasti. Tulevaisuutta luotaavat, } \\
\text { globaaleja kehityssuuntia arvioivat raportit megatrendeistä koettiin vähiten kiinnostavaksi (keskiarvo } \\
x=2.97 \text { ja keskihajonta } \sigma=1.079) \text { kaikista kyselyssä esillä olleista tietolähteistä. Myöskin neuvonnan (esim. } \\
\text { neuvontaorganisaatiot ja jalostavan teollisuuden neuvonta) tarjoamat ennakointimateriaalit } \\
\text { liiketoimintaympäristön muutoksiin liittyen olivat tietolähteistä vähiten merkityksellisimpien joukossa } \\
(x=3.39) \text {. Sen sijaan keskustelut toisten yrittäjien }(x=3.94) \text { ja neuvojien }(x=3.75) \text { olivat huomattavasti } \\
\text { merkityksellisimpiä strategista päätöksentekoa haettaessa. Vahvasti käytännön liikkeenjohtoon sidoksissa } \\
\text { olevat asiat kuten kannattavuuslaskelmat }(x=3.98) \text { ja saatavilla olevat lisäpellot }(x=4.09) \text { yrityksen }\end{array}$} \\
\hline
\end{tabular}


toimintaresursseina olivat luonnollisesti merkittäviä vastaajille maitotilan pitkän tähtäimen kehityssuuntia luotaessa. Samoin eläinten hyvinvointitutkimuksiin liittyvät tulokset koettiin tärkeiksi kautta linjan $(x=3.90, \sigma=0.854)$ Vastanneet maitotilayrittäjät arvostavat myös muiden yrittäjien kokemuksia, sillä erilaiset opintomatkat ja tilavierailut Suomessa olivat varsin merkityksellisiä yrittäjille $(x=3.61)$, joskin hajontaa vastausten välillä oli runsaasti $(\sigma=1.209)$. Ulkomailtakin oppia haetaan, vaikkakaan ei yhtä paljon kuin kotimaasta $(x=3.8)$.

Taulukko 2. Maitotilayrittäjien kokema ennakointimenetelmien merkitys oman tilan strategisessa päätöksenteossa arvioituna 5 -portaisella Likert -asteikolla

\begin{tabular}{lccc}
\hline Väittämä & Vastauksia & Keskiarvo & Keskihajonta \\
& $n$ & $x$ & $\sigma$ \\
\hline Keskustelut toisten yrittäjien kanssa & 135 & 3.94 & 0.991 \\
Opintomatkat ja tilavierailut kotimaassa & 135 & 3.61 & 1.209 \\
Ammatilliset lisäkoulutukset & 135 & 3.53 & 0.929 \\
Eläinten hyvinvointitutkimusten tulokset & 135 & 3.90 & 0.854 \\
Raportit megatrendeistä & 135 & 2.97 & 1.079 \\
Tuotantoteknologian uudet ratkaisut & 135 & 3.93 & 0.924 \\
Maatalouden internetsivujen tarjoamat tiedot ja & 135 & 3.42 & 1.018 \\
palvelut (esim. LUKE, MMM) & 135 & 3.79 & 0.917 \\
Ajankohtainen markkinainformaatio & 135 & 3.47 & 1.105 \\
Hintaennakoinnit yli viiden vuoden aikajänteellä & 135 & 3.98 & 1.026 \\
Kannattavuuslaskemat eri & 135 & 3.75 & 0.936 \\
markkinatilanneskenaarioilla & 135 & 3.39 & 1.001 \\
Keskustelut neuvojien ja konsulttien kanssa & 131 & 3.48 & 1.091 \\
Neuvonnan tarjoamat ennakointimateriaalit & 135 & 3.47 & 0.921 \\
Opintomatkat ulkomaille & 135 & 3.57 & 0.989 \\
Tutkimustoiminnan tuottamat & 135 & 3.58 & 1.335 \\
ennakointimateriaalit & 135 & 4.09 & 1.181 \\
Kuluttajakäyttäytymisen muutosten uutisoinnit & & & \\
Seuraavan sukupolven suunnitelmat & &
\end{tabular}

Analyysi jatkui eksploratiivisella faktorianalyysillä, jossa selvitettiin, löytyykö väittämiä yhdistäviä latentteja piirteitä. Aineiston ollessa suhteellisen pieni, huomiota kiinnitettiin latausten arvoihin valitsemalla vähintään 0.480 lataukset mukaan faktoreihin. Faktorianalyysi suoritettiin SPSS 25.0 -ohjelmalla hyödyntäen Varimax-rotaatiota. Kaiser-Meyer-Olkin (KMO) oli 0.825, joten aineiston todettiin sopivan faktoroitavaksi. Faktorianalyysin tuloksena saatiin neljä relevanttia faktoria (Taulukko 3), jotka yhdessä selittävät 58.12 \% vaihtelusta. Alkuperäisistä väittämistä neljä ei latautunut riittävän vahvasti yhteenkään faktoriin, nämä olivat eläinten hyvinvointitutkimusten tulokset, kannattavuuslaskelmat, seuraavan sukupolven suunnitelmat ja saatavilla olevat lisäpeltoresurssit. Ensimmäiseen faktoriin $\left(F_{l}\right)$ latautuneet muuttujat olivat yrittäjien verkostoihin ja verkostoitumiseen keskittyviä tietolähteitä. Liiketoimintaympäristöön läheisesti liittyvät lähteet lautautuivat toiseen faktoriin $\left(F_{2}\right)$, tähän faktoriin latautui viisi muuttujaa. Kolmannen faktorin $\left(F_{3}\right)$ muuttujien yhdistävänä tekijänä oli niiden toteuttajat eli lähtökohtaisesti neuvontasektorin eri toimijat. Neljännen faktorin $\left(F_{4}\right)$ yhdistävänä tekijänä oli niiden käyttämisen edellyttämä panostaminen halutun tiedon saamiseen. 
Taulukko 3. Eksploratiivinen faktorianalyysi väittämien ryhmittelyyn latenttien muuttujien mukaisesti, faktoreihin latautuneet arvot tummennettu taulukossa

\begin{tabular}{|c|c|c|c|c|c|}
\hline Väittämien määrä = 17 & & & & & \\
\hline & $\begin{array}{l}\text { Faktori } 1 \\
\text { Verkosto- } \\
\text { lähteet }\end{array}$ & $\begin{array}{l}\text { Faktori } 2 \\
\text { Liiketoimin- } \\
\text { taympäristö- } \\
\text { lähteet }\end{array}$ & $\begin{array}{l}\text { Faktori } 3 \\
\text { Asiantuntija- } \\
\text { lähteet }\end{array}$ & $\begin{array}{l}\text { Faktori } 4 \\
\text { Aktiivisen } \\
\text { tiedonhaun } \\
\text { lähteet }\end{array}$ & \\
\hline$\%$ varianssin selitysaste & $33.60 \%$ & $9.47 \%$ & $7.79 \%$ & $7.31 \%$ & $58.12 \%$ \\
\hline Eigenvalue & 5.71 & 1.61 & 1.32 & 1.24 & \\
\hline Rotatoidut faktorilataukset & & & & & Kommunaliteetti \\
\hline $\begin{array}{l}\text { Keskustelut toisten yrittäjien } \\
\text { kanssa }\end{array}$ & .930 & .101 & .115 & & .896 \\
\hline $\begin{array}{l}\text { Opintomatkat ja tilavierailut } \\
\text { kotimaassa }\end{array}$ & .560 & & .143 & .340 & .470 \\
\hline $\begin{array}{l}\text { Ammatilliset lisäkoulutukset } \\
\text { Eläinten }\end{array}$ & .554 & .256 & .237 & .103 & .461 \\
\hline $\begin{array}{l}\text { hyvinvointitutkimusten } \\
\text { tulokset }\end{array}$ & .429 & .407 & .237 & .103 & .422 \\
\hline Raportit megatrendeistä & .186 & .704 & .149 & .313 & .651 \\
\hline $\begin{array}{l}\text { Tuotantoteknologian uudet } \\
\text { ratkaisut }\end{array}$ & .387 & .533 & & .152 & .536 \\
\hline $\begin{array}{l}\text { Maatalouden internetsivujen } \\
\text { tarjoamat tiedot ja palvelut } \\
\text { (esim. LUKE, MMM) }\end{array}$ & .320 & .530 & .219 & .235 & .621 \\
\hline $\begin{array}{l}\text { Ajankohtainen } \\
\text { markkinainformaatio }\end{array}$ & .181 & .529 & & .213 & .380 \\
\hline $\begin{array}{l}\text { Hintaennakoinnit yli viiden } \\
\text { vuoden aikajänteellä }\end{array}$ & -.196 & .521 & .354 & -.102 & .472 \\
\hline $\begin{array}{l}\text { Kannattavuuslaskelmat eri } \\
\text { markkinatilanneskenaarioilla }\end{array}$ & .163 & .376 & .251 & .194 & .407 \\
\hline $\begin{array}{l}\text { Keskustelut neuvojien ja } \\
\text { konsulttien kanssa }\end{array}$ & .262 & & .774 & & .765 \\
\hline $\begin{array}{l}\text { Neuvonnan tarjoamat } \\
\text { ennakointimateriaalit }\end{array}$ & .196 & .272 & .737 & & .659 \\
\hline Opintomatkat ulkomaille & .258 & .135 & & .597 & .442 \\
\hline $\begin{array}{l}\text { Tutkimustoiminnan tuottamat } \\
\text { ennakointimateriaalit }\end{array}$ & .360 & .334 & .334 & .514 & .640 \\
\hline $\begin{array}{l}\text { Kuluttajakäyttäytymisen } \\
\text { muutosten uutisoinnit }\end{array}$ & .180 & .293 & & .485 & .387 \\
\hline $\begin{array}{l}\text { Seuraavan sukupolven } \\
\text { suunnitelmat }\end{array}$ & & & & .243 & .061 \\
\hline Saatavilla olevat lisäpellot & & & .118 & & .269 \\
\hline Cronbach's $\alpha^{*}$ & .770 & .757 & .774 & .668 & \\
\hline
\end{tabular}




\section{Tulosten tarkastelu}

Tässä tutkimuksessa aineiston muodostaa keskimääräistä suomalaista maitotilayrittäjää nuoremmat yrittäjät, joilla on myös keskimääräistä suurempi maitotila. Vastaajajoukon ollessa suhteellisen nuorta, eivät mahdollisen seuraavan sukupolven suunnitelmat ole vielä relevantti asia suurelle osalle tästä vastaajaryhmästä. Sen sijaan oman toiminnan kehittäminen oli merkityksellisessä roolissa aineistonäytteessä. Yrittäjistä iso osa $(n=79)$ ilmoitti jatkavansa ja pyrkivänsä laajentamaan maidontuotantoa seuraavien kymmenen vuoden aikana. Koska vastaajajoukossa on korostunut keskivertoa isompien tilojen osallistuminen tutkimukseen, on huomattava polkuriippuvuuden merkitys maidontuotannon jatkamista ohjaavana vaikuttajana. Isommilla tiloilla on jo tehty investointeja tuotannon laajentamiseen liittyen ja tilan kasvattaminen edelleen on luonteva kehityssuunta. Aineiston vinoutumisesta johtuen tuloksia ei voida yleistää, mutta niiden avulla voidaan havainnoida, miten maidontuotantoa jatkavat yrittäjät käyttävät erilaisia tietolähteitä strategisen päätöksenteon tukena. Näillä yrittäjillä on sisäinen motivaatio hakea tietoa, joka edesauttaa selviytymistä muuttuvassa liiketoimintaympäristössä.

Maitotilayrittäjille keskustelut eri tahojen kanssa ovat tärkeitä tietolähteitä oman maitotilan pitkän tähtäimen suunnitelmia laadittaessa. Erityisen kiinnostavaa on ero neuvojien konsulttien kanssa keskustelun ja neuvontaorganisaatioiden tuottamien ennakointimateriaalien käyttämisen välillä, maitotilayrittäjät vaikuttaisivat arvostavat keskustelua enemmän kuin tiedon hakemista itse (Taulukko 2). Tämä nostaa esiin kysymyksen, haluaako osa maitotilayrittäjistä tiedon tulevan heille kerrottuna sen sijaan, että itse käyttäisivät rajattua aikaresurssiaan itse tiedon etsimiseen, lukemiseen ja mahdollisten johtopäätösten tekemiseen. Maitotilayrittäjien tietolähteiden jaotteleminen sisäisiin ja ulkoisiin lähteisiin oli myös kiinnostava tarkastelukohde. Haase ja Franco (2011) havaitsivat pk-yritysten hyödyntävän sisäisiä lähteitä. Tässä aineistossa esiin nousi kuitenkin ulkoisten lähteiden merkitys ja tiedon etsiminen muiden yrittäjien kokemusten kautta.

Faktorianalyysin tuloksista oli nähtävissä verkostoitumisen merkitys maitotilayrittäjille ja toisilta yrittäjiltä saatavan osin kokemusperäisen tiedon vaikuttavuus. Verkostoitumisen merkitys on havaittu aiemmissakin tutkimuksissa (esim. Major ym. 2001), joissa on tunnistettu epämuodollisten verkojen omaavan etuja muodollisiin verkostoihin nähden tietoa haettaessa. Faktorit eroavat toisistaan tietolähteiden sisällön ja sisällön syvyyden osalta, $F_{4}$, aktiivisen tiedonhaun lähteet on laajaa liiketoimintaympäristön muutosten kuvaa luovien tietokanavien ryhmä. Ilmola-Sheppard ja Kuusi (2011) ovat tunnistaneet yrittäjien ennakointityötä tutkiessaan olevan yrittäjillä myös erilaisia tarpeita tiedon laadulle. Toisinaan tarvitaan hyvin laajaa ymmärryksen lisääntymistä, kuten $F_{4}$ :n kaltaisia lähteitä toimintaympäristön muutosten analysoinnissa. Toisissa tilanteissa painottuu tarve saada syvempi ja tarkempi kuva strategian toteuttamisen tueksi ja näissä tilanteissa korostuu monipuolisuus ja laajuus lähteiden valinnassa (Ilmola-Sheppard ja Kuusi 2011). Faktorianalyysin tulos $F_{2}$, liiketoimintaympäristölähteet, tukee tätä havaintoa. Faktoriin $F_{2}$ yhdistyy useita liiketoimintaympäristöä ja sen muutoksia indikoivia lähteitä eri aikajänteillä ja tarkastelutasoilla.

Isoissa yrityksissä toteutettua ennakointia tutkineet Daheim ja Uerz (2008) havaitsivat yksittäisistä ennakointilähteistä trendiraporttien olevan yrityksille merkittävimpiä. Tässä tutkimuksessa trendiraportit latautuvat osaksi faktoria $F_{2}$, joka painottuu lyhyen ja keskipitkän aikavälin muutosten seurantaan. Major ym. (2001) ovat luokitelleet informaatiolähteitä kolmeen ryhmään: tuotantoketjun lähteet, liiketoimintaa tukeviin lähteisiin sekä henkilöiden välisiin lähteisiin. Myös tässä tutkimuksessa havaittiin verkostojen $\left(F_{l}\right.$, verkostolähteet) nousevan esiin yrittäjien hakiessa tietoa strategisen päätöksenteon tueksi. Sen sijaan Hanssonin ja Fergusonin (2011) tutkimuksessa havaittiin toisilta yrittäjiltä ja koulutuksista saatavan tiedon vahvistavan päätöstä olla kehittämättä maidontuotantoa. Kuten Hansson ja Ferguson (2011) toteavatkin, kollegoiden kanssa keskustelu ja osallistuminen koulutustilaisuuksiin voivat vahvistaa ennalta asetettua päätöstä, jolle haetaan vahvistusta näistä kanavista. Tämä näkökulma on huomioitava myös tässä 
tutkimuksessa, sillä yrittäjiä ei pyydetty kyselyssä arvioimaan kunkin tietolähteen osalta niiden vaikutusta maitotilan kehittämiseen tuotantoa kasvattavasti tai tuotantoa vähentävästi.

\section{Johtopäätökset}

Tulevaisuuteen orientoituneet eli kasvuhakuiset yrittäjät vaikuttavat hyödyntävän ennakointia oman tilan johtamisessa. Merkittävässä roolissa ennakoinnissa ovat omien verkostojen kautta saatava tieto, mutta myös lyhyen ja keskipitkän aikavälin kehityssuuntia luotaavat lähteet. Suomalaiset maitotilat ovat pääosin perheviljelmiä ja yrityksissä käytettävissä oleva työpanos eli aikaresurssi sen mukainen. Rakennekehitys vie tilakokojen kasvua eteenpäin, jolloin tilojen työvoima kasvaa yrittäjän työn painottuessa johtamiseen. Aineistosta havaittiin tulevaisuusajattelun aikajänteen olevan vastaajille keskipitkälle suunnittelujaksolle ulottuva mikä on luontevaa, sillä maitotiloilla tuotantoympäristön investoinnit ovat pitkäkestoisia ja takaisinmaksuajat pitkiä sekä vastaajajoukko varsin nuorta. Näin ollen yrittäjät tulevat kohtaamaan erilaisia muutoksia liiketoimintaympäristössään. Muutoksista selviytyminen puolestaan vaatii ennakointia vähintään keskipitkällä aikavälillä ja niiden tietolähteiden käyttämistä, jotka täyttävät tietotarpeita.

Tutkimuksessa ei noussut esiin kuinka paljon yrittäjät käyttävät aikaa ennakointiin ja onko se täysin tunnistettua vai muun työn ohella toteutettua. Mikäli ennakointi on jatkuvaa, se voi tukea yrityksen strategian toteuttamista, kun uutta tietoa arvioidaan aiemmin kertyneeseen tietoon ja suhteutetaan oman maitotilan liiketoiminnan edistämiseen. Maitotilayrittäjien, tai laajemminkin kasvavien maatalousyritysten panostus toimintaympäristön ennakointiin on kiinnostava jatkotutkimuksen aihe.

\section{Kiitokset}

Tutkimus on osittain rahoitettu Oiva Kuusiston säätiöstä ja tutkimuksen ovat mahdollistaneet myös Jyväskylän ammattikorkeakoulun Biotalousinstituutti sekä Valio Alkutuotanto.

\section{Kirjallisuusluettelo}

Appiah, G. \& Sarpong, D. 2015. On the influence of organisational routines on strategic foresight. Foresight 17: 512-527. https://doi.org/10.1108/FS-11-2014-0067

Carini, G.R. \& Norman, P.H. 2017. Posturing your firm for the future: considering environmental uncertainty and managerial sentiment. Strategic direction 33: 37-39. https://doi.org/10.1108/SD-09-2017-0141

Field, A. 2018. Discovering statistics using IMB SPSS statistics. 5th edition. Sage publications.

Grenewald, J.A. 1987. The producer as decision-maker. Agrekon 26:43-46.

https://doi.org/10.1080/03031853.1987.9524111

Haase, H. \& Franco, M. 2011. Information sources for environmental scanning: do industry and firm size matter? Management decision. 49:1642-1657. https://doi.org/10.1108/00251741111183807

Hair, J.F., Black, W.C., Babin, B.J. \& Anderson, R.E. 2010. Multivariate Data Analysis. A global perspective. Pearson Prentice Hall. 7th Edition.

Hansson, H. \& Ferguson, R. 2011. Factors influencing the strategic decision to further develop dairy production - a study of farmers in central Sweden. Livestock science 135:110-123. https://doi.org/10.1016/j.livsci.2010.06.157

Hough, J.R. \& White, M.A. 2004. Scanning actions and environmental dynamism. Gathering information for strategic decision making. Managament decision 24:781-793. https://doi.org/10.1108/00251740410542348

Ilmola-Sheppard, L. \& Kuusi, O. 2011. Information filters as one of the means of managing strategic fit in a complex environment. Foresight 15:132-151.https://doi.org/10.1108/14636681311321130

Major, E., Asch, D. \& Cordey-Hayes, M. 2001. Foresight as a core competence. Futures 33:91-107.

https://doi.org/10.1016/S0016-3287(00)00057-4

Perkiö-Mäkelä, M., Hirvonen, M., Kinnunen, B., Koponen, M., Louhelainen, K., Mäittälä, J., Sipponen, J. \& Torpström, A. 2016. Työterveys ja maatalous Suomessa 2014. Työterveyslaitos. 196 p.

http://www.julkari.fi/handle/10024/130362 